\title{
The Vanishing Soviet Utopia in Hungary in the Light of de-Stalinization - Soviet Union as the Land of Modernization in the Hungarian Press 1950-1958
}

\section{Róbert TAKÁCS}

\author{
Politikatörténeti Intézet, Budapest \\ Institute of Political History \\ Alkotmány u. 2, 1054 Budapest, Hungary \\ takrobi@yahoo.com
}

What will the car of the future be like? - asked the party daily Népszabadság on 16 May 1982. The article says, the answer will be defined by Porsche, Volkswagen and Fiat - great Western constructers. ${ }^{1}$ Two and a half decades arlier - in 1958 - Népszabadság used a very different tone writing about cars: "New ZIL-111 swallow-tailed miracles keep gliding at a speed of 80-90 kilometres per hour among uncountable numbers of new Volgas, friendly humming, but very swift, new type, overhead-valve engine Moskvitches, not to speak about the legions of good old Pobedas, ZIMs and ZISes. One or two Chaikas, the new pride of Soviet motor industry, also appear." 2 A half a decade earlier the picture was somehow even different: Szabad Nép quoted from the book of Yuri Aronovich Dolmatovsky about a future car factory where machines put together the parts on an automatic assembly line and at the end of the line the engine of the newly constructed car starts up and the car rolls out on its own. ${ }^{3}$

Modernization in Hungary - and in Eastern Central Europe - has been more or less the synonym of Westernization for centuries. But in the examined period - in the 1950s - it was the first decade of a new anchor, the Soviet Union, when - publicly - the leading role of the Soviet Union in the world progress remained unquestionable. The Soviet Union was the model of modernization in 1950, and "gave the definition" of development also in 1958. The West was narrowed into the position of an antithesis of the Soviet-style modernization as the example of an inhuman, empty, exploiting modernization that is to be transcended. The skyscrapers of Moscow were presented as proofs that the state takes care of its citizens forming the city according to their needs, while Western skyscrapers were the signs of profit-hunting selfishness, alienating asperity and urban anarchy. ${ }^{4}$ Automation in Western countries led to growing unemployment and pauperization, but in Soviet environment it was meant to bring abundance for the people. ${ }^{5}$

\footnotetext{
1 Emil SZLUKA, Milyen lesz a jövő kocsija?, Népszabadság, 1982, Year 40, No. 113, 16 May. 2 István SZABÓ, Mi újság Moszkvában?, Népszabadság, 1958, Year 16, No. 308, 31 December. 3 Az épülő kommunizmus technikai csodái, Szabad Nép, 1952, Year 10, No. 28, 3 February. 4 Új magasépületek Moszkvában, Magyar Nemzet, 1953, Year 9, No. 192, 16 August.

5 György VARGA, S. Lilley: Az automatizálás és a társadalom, in: Közgazdasági Szemle, 5, 1958, 11, 1207-1209; Jenő VARGA, A jelenkori kapitalizmus és a szocializmus fejlődésének tendenciáiról, in: Társadalmi Szemle, 12, 1957, 10, 7-24.
} 
The paper examines the portrayal of the Soviet life in the Hungarian press between 1950 and 1958 by Hungarians seeing the Soviet Union with their own eyes. Their number is smaller than one would think knowing the new meaning of the old truth: ex oriente lux. The borders were not only almost totally shut down for the West, but also strictly controlled among the Soviet bloc countries. Individual travel was very limited; the Hungarian-Soviet relation was almost restricted to changes of delegations. ${ }^{6}$ Journalists were not among the welcomed ones: on a 'day of complaints' at the Agitation and Propaganda Department in November 1953 leading journalist Iván Boldizsár rebuked that "there had already been a chimney sweepers' delegation to the Soviet Union but journalists' ".?

Szabad Nép, the communist daily, published only 32 personal reports in 1950 and 41 in 1951 dropping back to 22 the next year and 12 in the year of Stalin's death. Nevertheless, 41 articles of 1950 stemmed from six delegations, two of which were sport teams. The experiments of 1951 were also collected in six different groups. The number of the travelogues and reports climbed back to 32 and 35 in 1956 and in 1957 showing the renewed propaganda effort of the Hungarian press direction. The trends - with lower numbers were much similar in the case of the non-party daily intended for urban intellectuals, Magyar Nemzet. ${ }^{8}$

\section{Diagram 1. Number of articles published in Szabad Nép/Népszabadság and Magyar Nemzet.}

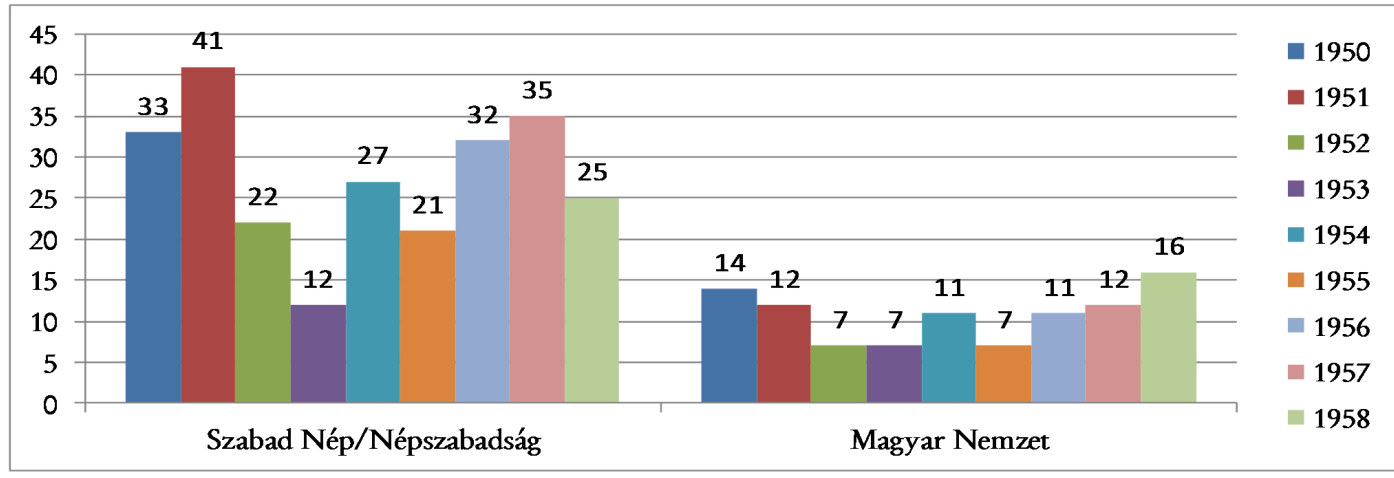

For the analysis, we primarily chose such articles of Szabad Nép and Népszabadság since due to their central role they were the forums where most visitors published their experi-

6 The number of Hungarians visiting the Soviet Union in the 1950s was the following: 1951: 2,479; 1952: 2,337; 1953: 2,530; 1954: 2,280; 1955: 3,744; 1956: 9,399; 1957: 10,563; 1958: 38,983. Source: Statisztikai Évkönyv 1957, 1958. About the passport regulations see: Péter BENCSIK - György NAGY, A magyar úti okmányok története 1945-1989, Budapest 2003.

7 Magyar Nemzeti Levéltár Országos Levéltára (The State Archives of the Hungarian National Archives; hereinafter referred only as MNL-OL), Magyar Dolgozók Pártja Központi Szervei - Central Authorities of the Hungarian Working People's Party (1946-1958) (hereinafter referred to only as "M-KS"), 276 fond (hereinafter referred to only as "f."), 89/192. örzési egység (hereinafter referred to only as "ő. e."), Records of the confidential press conference on 30 November 1953.

8 The central party daily changed its title for Népszabadság in November 1956. Magyar Nemzet was not published between November 1956 and September 1957. 
ences. Also, Népszabadság represented the most comprehensive approach towards Soviet life that was not restricted to a special profile like in the case of Magyar Nemzet which concentrated on three major issues: cultural life, foreign politics and peace propaganda. Our content analysis concentrates on the manifestations of modernization and modernity in the Soviet life as seen by the Hungarian narrators. What did they perceive or feel appropriate to tell about a modern Soviet Union? How were these building blocks of modernity subjected to a Soviet utopia and how did they shift during the de-Stalinization process? And also - what changes stemmed from the broad Soviet or the Hungarian de-Stalinization project and what elements constituted the de-Stalinization of the Hungarian and Soviet publicity? There could have been other frameworks for an analysis of the perception of the Soviet Union, if instead of modernization we would have chosen another central concept: cultural liberalization. It would lead us to the world of cultural transfers for which personal report is not the most appropriate genre but book reviews and film and theatre critiques. However, from 1958 we can find loads of artistic accounts on Soviet film and theatre workshops mediating the experiments of the thaw culture in Magyar Nemzet.

By restricting our focus on the symptoms of the modernization of Soviet life - accepting the conclusion of Ronald Inglehart that modernizing societies follow some coherent patterns ${ }^{9}$ - the analysis covers the issues mentioned the most frequently in the reports: industrialization, urbanization and the cultural aspects of modernization from rising educational levels through mass media to secularization. Some other important aspects of modernization had strange refractions in socialist countries - like individuation, bureaucratization or entrepreneurial motivation. Individuation was something to be transcended: the utopian ideal was collective. Bureaucratization was left open to public criticism as the crab of the brave new world. On the one hand, entrepreneurial motivation was deprived of the profit motive but on the other hand, a cult of innovators was nourished. Anyway, these motives had little space in the depictions of the Soviet utopia.

\section{'Handbook for Visitors' - Program Articles of Approaching the Soviet Life}

The articles of this narrow decade were written in very different political situations. After the death of Stalin the new Soviet leaders had to reconsider the whole political spectrum: de-Stalinization - with different concepts in the heads - began the very day Stalin died. ${ }^{10}$ This shift pushed Hungary much further in its own de-Stalinization process than any other country of the block: the new Prime Minister Imre Nagy pursued a clear-cut de-Stalinizing alternative to the Rákosist line till early 1955 when Mátyás Rákosi successfully led a counter-offensive. After a year of re-Stalinization, the $20^{\text {th }}$ Congress of the CPSU brought a new situation which in Hungary - contrary to the maverick Poland - ran into revolution crushed by Soviet tanks. Journalism had its own twists and turns in these years: journalists - lead

9 Ronald INGLEHART, Modernization and Postmodernization. Cultural, Economic and Political Change in 43 Societies, Princeton 1997, 8-11.

10 William TAUBMANN, Khrushchev: The Man and his Era, New York 2003, 245-262. 
by the staff of Szabad Nép twice 'revolted' by the side of reform politics. First in October 1954, then in June 1956. ${ }^{11}$ They supported the revolutionary aims - with different motivations and ideals - and lost their short lived autonomy again.

From the swarm of the examined articles we can detect so called 'program articles' that define a new approach of seeing and mediating the Soviet utopia that reflect the above breakpoints which usually followed the political changes with several months' delay. The first years of the 1950s were characterized by discovering the Hungarian future in the Soviet Union and by showing up examples to follow and to mobilize. As Almási István, the journalist accompanying the third Hungarian peasants' delegation put it: "It seemed as if we had turned ahead the pages in the book of history. What we have seen, that urges each delegate to turn the wheels of time faster, so that the peasants could live such rich and happy lives in our country as well."12 From the autumn of 1953, it shifted for presenting the Soviet Union in its development and overcoming uncritical model setting. "Till now our reviews on the Soviet Union in most cases only talked about ready achievements, and did not reveal by overcoming what difficulties these results had been achieved and what obstacles will have to be exceeded on the road to communism." - declared Béla Kelen, the first secretary of the Hungarian-Soviet Society in October 1953. ${ }^{13}$

The short-lived re-Stalinization period of 1955/1956 did not launch a central propaganda vision against this de-Stalinized presentation of Soviet world so the next breakpoint was brought by the $20^{\text {th }}$ Congress. However the catchwords of facts and objectivity conveyed the message of the liberation of thinking and not modernization. As the literary scholar Pandi Pál penned: "We must get rid of the imbibed stereotypes of plenty of one-sided or false travelogues, theatrical novel figures and articles far from reality in order to see the Soviet life as it is... [And those who] keep 'promoting' the Soviet Union instead of informing through facts, deprive the people, the Hungarian people too, from a huge political resource." 14

During the year following the revolution the reconsideration of Soviet-propaganda and the reinforcement of Hungarian-Russian friendship were on the agenda. Journalists visiting the Soviet Union thrived to prove the goodwill of the mighty empire that was - as an aside - modern, too. "We have no bigger bounden duty than make the Hungarian people understand that the dirty broadside of the counter-revolution against the Soviet Union was built on sheer lies..." - wrote Károly Szamosi, the deputy editor of Népszabadság in June 1957 adding that: "»leading" and other clichés are not going to be every second word of mine - as well as I am not going to be haunted by the pose of fake-objectivity". ${ }^{15}$ Modernization partially returned to spotlight after 4 October 1957: the launch of the Sputnik. István Földes, the other deputy editor of the party daily started his article with the pictures of the May Day decoration of the post headquarters in Moscow. The neon lights showed

11 Róbert TAKÁCS, Újságírói szerepfelfogások 1954 és 1956 között Magyarországon, in: Médiakutató, 7, 2006, Winter, 7-24.

12 István ALMÁSI, Kolhozparasztok házaiban, Szabad Nép, 1951, Year 9, No. 195, 25 August.

13 Béla KELEN, A szovjet élet legjellemzőbb vonása: szerető gondoskodás a dolgozó emberről, Szabad Nép, 1953, Year 11, No. 279, 6 October.

14 Pál PÁNDI, Előszó útijegyzetekhez, Szabad Nép, 1956, Year 14, No. 121, 30 April.

15 Károly SZAMOSI, A nézőpontról, Népszabadság, 1957, Year 2, No. 147, 23 June. 
the nuclear-powered icebreaker; the nuclear plant; the TU-104 aircraft and of course the Sputnik. In the year of the Brussels expo, the main effort was to present the Soviet Union as high-tech superpower. ${ }^{16}$

\section{Changing Depictions of the Soviet Utopia}

In the following chapter, we will examine how these changing attitudes characterized writing about the different spheres of modernization, how clichés of representation were dissolved or adjusted to the new stances and political turns.

\section{a) Industrialization}

Industry remained a prominent topic in the whole decade. De-Stalinization brought a shift in scales, light industry, the production of consumers' goods gained in importance, but heavy industry reserved its dominant position. For visitors industry - the factory, the shopfloor - was a ritual space for collecting 'Soviet experience'. However the number of these shrines was limited: the names like ZIS, Elektrosila, Ordzhonikidze were recurring.

In point of industrialization the narratives of the early 1950s acted upon the classical Stalinist 'socialist industrialization' concept of heavy industry driven modernization. The travellers reported from factories, mines and power plants, while newspapers often reviewed the Soviet press on huge transformation of nature projects, however the latter seemed not be admitted to the itineraries of foreign visitors. Witnesses to Soviet life saw production with the high-tech vision of multiplication of human power by machines: "Here machines do the navvy work, machines dig the grounding for the buildings, machines top up the railway embankment, machines tear down the hills, machines delve the new watercourses and abolish the old ones, machines and machines." ${ }^{17}$ Machines were presented as the means of conquering the nature. In this Soviet utopia of creating abundance with the help of modern science and technology nothing was deemed beyond possibility. "An engineer, for example, needs greater, flat territory for the construction of a factory or a city. Mountainous landscapes do not permit the reasonable allocation of factory buildings and mansions. Few well figured nuclear explosions and the flat surface appears among the mountains." - wrote the party daily in an editorial. ${ }^{18}$

Hungarian travellers mediated this Fordist vision of automatized production ${ }^{19}$ and the main narrative of these visits was time travel to rooms where machines did their jobs from the beginning to the end with one or two workers at controlling panels pushing buttons and pulling arms. Spaciousness was an often repeated impression of the eye-witnesses. Ödön Kerényi the engineer of the "Mátravidéki" Power Plant gave the following description of

16 István FÖLDES, Első́k a világon, Népszabadság, 1958, Year 16, No. 133, 6 June.

17 Pál SZABÓ, A Lenin-kolhozban, Szabad Nép, 1950, Year 8, No. 205, 3 September.

18 Pillantás a jövőbe, Szabad Nép, 1950, Year 8, No. 28, 2 February.

19 Stalinist industrialization did not only rely on Ford as a vision but also as an important source of technological transfers. J. D. PARKS, Culture, Conflict and Coexistence. American-Soviet Cultural Relations, 1917-1958, Jefferson and London 1983, 34-36. 
a hydroelectric station near Moscow: "the units of the plant start automatically and stop automatically as well, and can be operated from the distance. The engineer on duty is the only man living at the plant, who is notified by an automatic apparatus in case of trouble."20 All in all, mechanization and automation was mediated as the direct road to the dissolving difference within society, where one's position in the division of labour does not imply inequalities, where physical and intellectual work merge.

The main shift from 1953 was not turning away from mechanization and automation but new fields of automatized production were discovered like sweets and chocolate factories, stockings production in 1953, and house factories from 1954. The description of the Lyubertsy house factory was almost the same as the earlier versions: while concrete blocks, barrels, bathtubs and sacks were travelling above the head of the narrator, the workers "pushed some button, turned some stud, trod on some pedal and made phone calls - that was all. The well-oiled machines were working almost noiselessly." 21 Hungarian visitors started to emphasize other spheres of economy following the shifts of de-Stalinization. Ernő Mihalyfi found the symbol of light industry and consumers' needs in the spinning-tops produced in "Red Proletar" factory, the citadel of heavy industry, which was offered in great variety in the newly opened Gosudarstvenniy Universalniy Magazin (GUM) shopping mall. The spinning top finally appeared at a third place, the child care room of a cinema. This choice seems to be a perfect journalistic invention to illustrate that the changes unfolded at all spheres of life, to underline the growing importance of light industry, to pay attention to consuming besides production, privacy besides collectivism. ${ }^{22}$ Earlier reports also showed flashing pictures of abundance of goods ${ }^{23}$ - but when GUM "replaced" the more modest CUM (Centralniy Universalniy Magazin) the genre of shopping mall report was born. ${ }^{24}$

Some narratives of industrialization did not change at all. The narratives of great transformations survived in the de-Stalinization years. Stories of the sudden development of the Soviet periphery remained the examples of successful Soviet modernization with nations and territories that jumped decades, even centuries under Soviet rule. ${ }^{25}$ They had two sub-narratives - unwittingly reflecting the two main currents of modernization theories: ${ }^{26}$ the industrialization driven modernization and the culture driven modernization. Before 1953, the latter implied the praise of the so called 'Stalinist national policy' that was deemed to promote the birth of modern nations with their own literature and native language cultural institutions. ${ }^{27}$ As an 1950 article put it: "We could speak of nations (like

20 Beszélgetés egy sztahanovista mérnökkel a Szovjetunió villamosításának ötéves tervéről, Szabad Nép, 1952, Year 10, No. 220, 13 September.

21 Béla ILLÉS, Kőművesek, Szabad Nép, 1954, Year 12, No. 343, 9 December.

22 Ernő MIHÁLYFI, Búgócsiga. (Moszkvai jegyzetek), Szabad Nép, 1954, Year 12, No. 208, 27 July.

23 Ferenc KARINTHY, Moszkvai hétköznapok, Szabad Nép, 1951, Year 9, No. 12, 16 January; Zoltán ZELK, Szovjet gyerekek, Szabad Nép, 1951, Year 9, No. 13, 17 January.

24 Gyula KÉKESDI, Ahol milliók vásárolnak, Szabad Nép, 1955, Year 13, No. 320, 19 November.

25 For a historical approach see: Adrienne Lynn EDGAR, Tribal Nation: The Making of Soviet Turkmenistan, Princeton 2004.

26 INGLEHART, 8-9.

27 For the national policy of the Soviet Union see: Yuri SLEZKINE, The USSR as a Communal Apartment, or How a Socialist State Promoted Ethnic Particularism, in: Slavic Review, 53, 1994, 2, 414-452. 
the Kabards), who did not even have an alphabet before the revolution - and today a row of their poets and artists serve the issue of socialism on their mother tongue. We can assert that people are reading the classics of Russian and world literature in their native language in the flourishing villages built on the place of former Kirgiz yurts. "28 However, in most cases industrialization and cultural upheaval were meant to go hand in hand. For example, journalist Endre Barát came to the following conclusion after talking to a pioneer nickel miner from Norilsk in a Moscow cafeteria: "Where the silence of the dead nature was frightening and people lived beastly lives wrestling with seals, polar bears and wolves - there ascends a new, great city. And between its walls electric stations keep buzzing, electric lights are flooding and warmth is spreading in human homes. And music is ringing, voice of songs is flying, statues and paintings are bringing delight - because art and science were conceived and keep evolving in the mirthless polar night." 29

\section{b) Urbanization}

Urbanization was also a central building block of such narratives of transformation. Articles often spoke of rapid growth of cities with houses erected within months, even weeks. The visitors offered stories of the birth of new towns that grew out of the earth or from unknown small villages ${ }^{30}$ and the rebirth of old towns after the war like Stalingrad, Kiev, Minsk. A vision of transformation of the nature of the town was only part of the late Stalinist narrative and was taken from Soviet sources. Like the metamorphosis of Nizhniy-Novgorod, the town infamous for "fairs, banquets of traders and debauchery" from which the educating power of Soviet rule "extracted the century long lifestyle, morals and habits". ${ }^{31}$

The very symbol of rapid urbanization was Moscow metropolis. Returning visitors were surprised at few years' or few decades' great changes when discovering new parts of the city. The popular writer Gyula Illyés hardly could find the post headquarters in the shadow of the new towers in 1955, while two decades earlier in 1934 Hungarian emigrant communists had showed it to him proudly as the emblematic face of modern Moscow. ${ }^{32}$ Hungarians were spelled by the waves of metropolitan traffic - by the flow of cars, the total lack of horse wagons and of course by the monumental Moscow underground system. They kept registering the late-Stalinist symbols of the greatness of the Soviet Empire, the skyscrapers. The 'real jewel' among them was the Lomonosov University on Lenin Hill. It was depicted as the modern palace of science and in a 1952 account as the opposite of "damp-walled, obsolete Western European universities". ${ }^{33}$ De-Stalinization first reached the image of these skyscrapers and then themselves, too: in December 1955 cheap type-houses de-

28 Harminc év alatt évszázadok, Szabad Nép, 1950, Year 8, No. 16, 19 January.

29 Endre BARÁT, Történet a sarki fény városából, Népszabadság, 1958, Year 16, No. 268, 12 November.

30 The examples from Szabad Nép were the following: Tahia-Tas, (1952), Irkutsk (1953), Volzhskiy, Nova-Kakhovka, Elektrostal, Zhigulevsk, Mingechaur, Oktyabrsk, Polunochnoye (1955), Stavropol, Igarka (1958).

31 F. PANFJOROV, Az új születése, Szabad Nép, 1950, Year 8, No. 303, 31 December.

32 Illyés Gyula beszámolója a Szovjetunióban tett útjáról, Szabad Nép, 1955, Year 13, No. 356,25 December.

33 Sándor NAGY, A béke fővárosa, Szabad Nép, 1952, Year 10, No. 127, 31 May. 
throned them in urban planning for good. ${ }^{34}$ The utopia of reaching to the skies was relieved by the more humble but ambitious project of building new two-room flats for every family. The new moderate urban utopia of microraions offering all the services that a family might need found its symbol in the garden. ${ }^{35}$ "The city of the future will look like a huge garden. Nice, simple, cheerful looking houses will fall in line without the sea of stones among which one gets lost." 36

But at the same time, the changing journalistic attitude amended the vision of high-rise buildings with the wooden hovels in their legs. As Pandi Pal put it in 1956 - "Those who turn away their heads seeing the one-storied wooden houses cannot take notice of the fact that these rising new blocks are the stairs of communism. "37 The new approach broke with the selective perception of urban realities and used the synod of old and new for demonstrating the direction of progress. 'Honest reporting' even shed light on Gorkyan misery contrasted to the new-fangled hotel equipped with express lifts and air cooling representing the new, international image of Moscow: "These wooden shanties are still standing in the neighbourhood: there is a whole quarter of them, and if you take a walk and look around, I am not overstating, you can see such yards that you have only seen on movies or stages as the settings of Maxim Gorky's masterpieces. "38

The Soviet cities showed their new faces in the reports - besides being the signs of grandeur and production, they had become the garden of their inhabitants. For example reports from Stalingrad emphasized that the Volga-bank was cleared from the factories demolished during WWII. "Now the Volga is given back to the local people: primarily dwelling-houses, culture houses, restaurants and schools are built by the bank of the huge river. A lot of parks are created and every street is afforested." 39 The squares where war heroes used to contain the German army were full of children playing by the fountains. ${ }^{40}$ The parks and river banks of the city became the spaces for joy and leisure time. The communist writer Tibor Déry reported on the cavorting of young Leningraders at the river Neva who "found it appropriate to inform the whole world but at least whole Leningrad about their daring venture", while István Kulcsár enumerated the delights of an afternoon at the Kirov-park. ${ }^{41}$

34 Stephen V. BITTNER, The Many Lives of Khrushchev's Thaw: experience and memory in Moscow's Arbat, Ithaca 2008, 114-116.

35 Mark B. SMITH, Khrushchev's promise to eliminate the urban housing shortage: rights, rationality and the communist future, in: Soviet State and Society under Nikita Khrushchev, Melanie ILIC - Jeremy SMITH (eds.), New York 2009, 29-33.

36 Ferenc VAJDA, Ifjú szovjet városok, Szabad Nép, 1955, Year 13, No. 5, 6 January.

37 PÁNDI, Előszó..., Szabad Nép, 1956, Year 14, No. 121, 30 April.

38 Ernő URBAN, Moszkvai hétköznapok, Népszabadság, 1958, Year 16, No. 183, 3 August.

39 Béla KELEN, A szovjet élet legjellemzőbb vonása: szerető gondoskodás a dolgozó emberről, Szabad Nép, 1953, Year 11, No. 279, 6 October.

40 VAJDA, Ifjú..., Szabad Nép, 1955, Year 13, No. 5, 6 January.

41 DÉRY, Útijegyzetek..., Szabad Nép, 1954, Year 12, No. 192, 11 July; István KULCSÁR, Kora nyári délután a leningrádi Kirov-parkban, Szabad Nép, 1955, Year 13, No. 162, 13 June. 


\section{c) Rural Modernization}

Urbanization was presented as the key trend of the Soviet village, as well. In the early 1950s, kolkhoz villages were shown through newly built city-like houses, the first multi-story buildings (culture houses, schools, local hospitals, child care facilities), that is to say the signposts of the modern state. Through modern machines on the fields, mechanized stockfarms and radio centres. Finally, through scientific methods - that for example created the 'modern type of cotton' which could be harvested by machines. Kolkhozes, machines and scientific methods were framed into a kind of communist holy trinity by Péter Veres: "The rural producing community - the kolkhoz - stands in the middle, and on one side there is science and on the other side technology." 42

The narratives of mechanized agricultural work followed the same clichés as the reports on underground construction or automatized mines. A well-elaborated description from the experiences of the third peasant delegation drafted so: "here people merely administer the machines. The combines, the trucks, the "grain canon «, that »shoots" the grains of wheat far while the wind clears and dries seeds. The grain runs to the warehouse on elevators and conveyor belts, or wherever the operator wishes." 43 Machines were the foundation of the rural Soviet utopia, the merger of industrial and agricultural work. As Péter Veres put it, the combines "turned the gruelling rush of harvesting and thrashing into a machinists' industrial job". ${ }^{44}$ András Pesuth came to the same conclusion from the point of work organization: "tractorists and combine drivers work according to charts and pre-calculated schedules in many kolkhozes like the workers of well-organized factories." 45

While in the later years this rural vision lost its coherence, machines remained the earnest of agricultural modernization. Machines abode the main attraction of the Moscow agricultural exhibition and machines helped to transform the virgin lands. On the other hand, science stepped back. In the late-Stalinist utopia of mastering the nature everything seemed possible: tea and lemon plantations in Transcarpathia, new seas in the middle of the land and changing climate by the alteration of the way the rivers flow. Instead, an old face of the village was presented: the crowd of those who did not represent the superior Soviet people, those who were unwilling to enthuse over newer and newer methods and had to be won again and again. The portrait of the Ukrainian kolkhoz brigade leader Praskovya Maximovna Bondarenko revealed such attitudes even after a quarter of a century's kolkhoz farming. "Like of blind kittens, that is how your heads should be pushed into the milk so that you understood what good is." - she kept scolding her fellows. ${ }^{46}$

The modernization of the village was interpreted as a force that brought abundance for the peasants. In the years of the intensive kolkhoz propaganda the core of the rural utopia was welfare. 'Millionaire kolkhoz' was used as a standing locution; however after the great

\footnotetext{
42 Péter VERES, Egy ukrajnai kolhozban, Szabad Nép, 1950, Year 8, No. 196, 24 August.

43 Gábor MOCSÁR, "Kommunista világítótorony", Szabad Nép, 1951, Year 9, No. 205, 2 September.

44 Péter VERES, Két bőtermésű kolhoz földjén, Ukrajnában, Szabad Nép, 1950, Year 8, No. 201, 30 August.

45 András PESUTH, Aratás a Szovjetunióban, Szabad Nép, 1952, Year 10, No. 158, 6 July.

46 V. OVECSKIN, Praszkovja Makszimovna, Szabad Nép, 1955, Year 13, No. 113, 24 April.
} 
kolkhoz unions of 1950 essentially all kolkhozes became millionaires. ${ }^{47}$ Peasant delegates kept counting peasant incomes, entered spacious houses richly furnished with 'bourgeois comfort': carpets, chandeliers, paintings, desks, book-shelves and radio sets. 'Doubting Thomas' Hungarian peasants opened up cloakrooms to see full packed shelves of practical and modern clothes, and Soviet peasant fascinated them with tables set as if shaken out from the horn of plenty. And wherever they went, registered the number of private car owners: 13 in the Georgian Beria-kolkhoz in 1950, 42 in an Abkhazian tea-planting kolkhoz in 1954, 50 in an Uzbek two years later etc.

The peasant fellow-travellers of István Almási in 1951 were bantering on the gallant hospitability of the villagers of Dagestan: "They are not staying at kolkhoz peasant but in a municipal hotel. Since there were so many rooms, beds and ample furniture." 48 Later a more realistic picture of the Soviet village appeared with wooden houses and unpaved streets. However wooden houses also served as the counterpoint of the emerging new. In rural environment the television antennas on top of old blockhouses symbolized modernization: "only the television antennas spawning on top of the roofs testified that we are not in a Russian fairy land, but in 1955 in the land of socialism". ${ }^{49}$ In the Soviet Union, television sets had reached 1 million households by 1955 and 5 million by 1960,50 which must have been impressive for a Hungarian visitor where television broadcast only began in 1957. As well as cars, Moskviches and Pobedas that composed a "bizarre but soul-stirring perspective" parking in front of adobe houses. ${ }^{51}$

\section{d) Culture for the Masses}

"The unbelievable scale of learning enthrals the visitor of the Soviet Union" - nailed down the mathematician György Alexits, the chairman of the Hungarian Academy of Sciences whose delegation visited all levels of education and science institutions from the Tbilisi pioneers' palace through universities to the Soviet academy. ${ }^{52}$ Mass culture was depicted as one of the central achievements of the everyday Soviet life in the whole period. Travellers found a society of 'life-long learning' where training fever were not confined to schools and universities, but also pervaded factories during and after work hours, culture houses and pioneers' palaces. In this learning universe the most important question of the young female workers of the Stalin Car Factory was whether young Hungarian workers also studied a lot, because they kept training themselves all the time. ${ }^{53}$ 'Learning factory' was also articulated

47 The aggregated income of the 78,900 kolkhozs of the Soviet Union was 94,6 billion Rubel in 1957 which meant a 1,2 million Rubel average income. See: Károly GARAMVÖLGYI, A mezőgazdaság irányításának új vonásai a Szovjetunióban, in: Társadalmi Szemle, 13, 1958, 7-8, 22.

48 István ALMÁSI, Kolhozparasztok házaiban, Szabad Nép, 1951, Year 9, No. 198, 25 August.

49 Márton HORVÁTH, Először a világon. A magyar újságíró-küldöttség látogatása a szovjet atomerőműben, Szabad Nép, 1956, Year 14, No. 1, 1 January.

50 Kristin ROTH-EY, Finding a Home for Television in the USSR 1950-1970, in: Slavic Review, 66, 2007, 2, $278-282$.

51 István SIMON, A pálmák és havasok hazájában, Szabad Nép, 1954, Year 12, No. 167, 16 June.

52 György ALEXITS, A szovjet tudomány váraiban, Szabad Nép, 1950, Year 8, No. 102, 4 May.

53 Józsefné KAKUK, Három felejthetetlen hét a Szovjetunióban, Szabad Nép, 1952, Year 10, No. 119, 22 May. 
in the 1956 reports - before the $20^{\text {th }}$ Congress. ${ }^{54}$

The level of education and the mass consumption of culture was a constant topic in all reports. As an inevitable attachment, kolkhoz and factory visits involved the description of the culture houses and libraries. Soviet people shown in the newspapers were queuing at only two places: bus stops and museums, which were always crowded by all layers of society; transit travellers spent their one or two hours in exhibition rooms, where people were looking at pieces absorbedly. Hungarian visitors kept pursuing the strife to grab the essence of the 'Soviet person'. Besides absolute politeness (the Soviet is the man who escorts you to the hotel hall when you ask which underground to take), communality (the Soviet man is the conscious promoter of the public good) and thriving for the better, the most frequent answer was related to 'kulturnost' - 'culturedness'. Soviet people were reading per definition: not only at train stations and tea houses but the stewardess on the plane and the cowherd woman in red headscarf by the brook. ${ }^{55}$ As the music historian Bence Szabolcsi summarized in 1951: "I have seen the truck-driver who was reading Gorky at the wheel while waiting, the Kirgiz hunter searching for zoological literate in a bookstore, the Mordvin student explaining the folk poetry of his homeland, the young Ukrainian scientist, whose father was an illiterate peasant and the Kazakh composer, who was trying to form an opera from the old melodies of his nation." ${ }^{56}$ Soviet - high-level, educating - mass culture was also a frequent antithesis of Western commercial mass culture.

\section{e) Secularization}

Secularization was not an organic element of the description of Soviet culture. Religious life was hardly mentioned as part of Soviet realities. There is only one exception before 1953, but not by Hungarian witnesses: a British workers' delegation was reported to have participated on a Catholic mass in the St. Louis Church of Moscow. ${ }^{57}$ This article was published in Magyar Nemzet, which was the daily newspaper intended for the religious people as well. No wonder that when the main massage was the freedom of religion its forum was this organ: in 1958 the 'peace priest' MP Richárd Horváth shared his experiences of unrestricted church activity with the readers of Magyar Nemzet. ${ }^{58}$ On the other hand Népszabadság mediated a distinct picture sticking to the principle that religiousness is a private affair but as a social phenomenon not indifferent for the party. ${ }^{59}$ The flashing religious figures of the de-Stalinization period were old man always contrasted to the young. The icon hanged on the wall at the young factory worker's house for the sake of the grandma, but she was not

54 Ernő BAJOR NAGY, Magyar újságíró-küldöttség a Szovjetunióban. II., Szabad Nép, 1956, Year 14, No. 20, 20 January; Ernő BAJOR NAGY, Magyar újságíró-küldöttség a Szovjetunióban. III., Szabad Nép, 1956, Year 14, No. 21, 21 January.

55 Tibor DÉRY, Útijegyzetek a Szovjetunióból, Szabad Nép, 1954, Year 12, No. 192, 11 July; Endre BARÁT, Békevonattal a Szovjetunióban, Magyar Nemzet, 1957, Year 13, No. 16, 26 September.

56 Bence SZABOLCSI, Tettekre kötelező találkozás, Szabad Nép, 1951, Year 9, No. 112, 16 May.

57 Mit láttak az angol munkások a Szovjetunió templomaiban?, Magyar Nemzet, 1950, Year 6, No. 148, 29 June.

58 Richárd HORVÁTH, A barátság útján, Magyar Nemzet, 1958, Year 14, No. 110, 11 May; Richárd Horváth, Milyen az új ember?, Magyar Nemzet, 1958, Year 14, No. 137, 12 June.

59 Elemér BALOGH, A vallás a Párt és az állam szempontjából, in: Társadalmi Szemle, 5, 1950, 7-8, $624-626$. 
a churchgoer any more. ${ }^{60}$ Pál Pándi heard an old Muslim worshipping his god, but a young boy turned to him and said "Allah nyet", and like on a Hollywood kitsch Tchaikovsky's music sounded out from the radio and the electric lights - "lamps of Ilyich in Asia" - were turned on. ${ }^{61}$ And in 1958 a bearded man stepping out of a Moscow church on an autumn day grumpily kicked away the children's ball after making the sign of the cross. ${ }^{62}$

Secularization was of course a hidden massage of all articles emphasising the role of science in the transformation of the Soviet life. Opposite to religiosity science was depicted as something young - especially the leading field, nuclear technology which was found to be the most feasible symbol of a young science with young scientists in a young country. As the deputy editor of Népszabadság wrote in 1958: "Two young men in blue overalls are working by one of the dash panels. One of them is holding a screwdriver; the other one is turning a knob on the instrument. You might think that they are assembly workers between 25 and 30. Professor Dzhepelyov introduces us the two 'mounters'. Both are the doctors of physical sciences. Wherever you look, you see young faces." 63 Also, at least two references gave the symbolic description of secularization. One of them was taken from the French communist daily, I'Humanité. Roger Garaudy saw the new Lomonosov University as "a 30-storey building overtopping the city behind the laces of scaffolding, white like a new church". ${ }^{64}$ The Hungarian observer set the Moscow of 1918 against the 1957 capital city and modern Moscow also won a symbolic battle over the old religious Moscow. The new buildings of the metropolis swallowed the old landmarks, the three hundred and some steeples, which could not orientate the visitor any more. ${ }^{65}$

\section{De-Stalinization in General and in the Press and the Vanishing Utopia}

To see the changing portrayal of Soviet life we have to examine what were the consequences of the wide de-Stalinization process and what stemmed from the de-Stalinization of the press. First of all, we have to stress that de-Stalinization of press and publicity was different in the Soviet Union and in Hungary since both were searching the ways in their own roots. Soviet journalism re-discovered the zest of the 1920s and was urged to be the partner of the party in defining the socialist project. It thrived to grab the new, the great small sensations in the everyday life and reveal the obstacles of the emerging new. Its handbook was the 700-copy issue titled 'Dyen Mira' which illustrated through the events of one single day - 27 September 1960 - how the world is shaping. ${ }^{66}$

60 Pál PÁNDI, Emberek és számok. Útijegyzetek a Szovjetunióból III., Szabad Nép, 1956, Year 14, No. 126, 6 May. 61 Pál PÁNDI, A fények városa. Útijegyzetek a Szovjetunióból IV., Szabad Nép, 1956, Year 14, No. 136, 16 May. 62 Imre DOBOZY, Munkásünnep előtt, Népszabadság, 1957, Year 2, No. 262, 6 November.

63 FÖLDES, Elsők..., Népszabadság, 1958, Year 16, No. 133, 6 June.

64 Roger GARAUDY, A moszkvai Lomonoszov Egyetemen, a világ legnagyobb egyetemén, Magyar Nemzet, 1953, Year 9, No. 226, 26 September.

65 Géza JUHÁSZ, A világ fővárosa, Népszabadság, 1957, Year 2, No. 206, 1 September.

66 Thomas C. WOLFE, Governing Soviet Journalism. The Press and the Socialist Person After Stalin, Bloomington - Indianapolis 2005, 48-69. 
Hungarian journalism tried to learn and use this attitude but was more concerned with the rehabilitation of information and the rehabilitation of the reader, which meant producing newspaper-like journals with fresh news and readable articles. Furthermore, as an unintended consequence, de-Stalinization brought de-Sovietisation in two aspects. First, newspapers abandoned the program of copying Soviet journals. On the 30 October 1953 confidential press conference journalists attacked the attitude of "the more consistently we follow the Soviet press, the better". The meeting at the Agitation and Propaganda Department of the party became a kind of complaint day. Journalists disapproved of the depth of following the Soviet example, expunging traditional genres of Hungarian journalism like glossaries, subjective editorials and feuilletons, expressed their discontent with the consequences of the Soviet press role model which even went to the typographic mimicry of Pravda. Coverage of foreign politics had faded: while journalists formally 'accepted' that Soviet newspapers might have other concerns in reacting with a time puffer, Hungarian press - in a country listening to Western radio broadcasts ${ }^{67}$ - should account all events immediately. Also, it was deemed counterproductive to avoid any information on a question before the Soviet press takes position and to take over Pravda editorials after Soviet measures instead of writing about it unbound and colourfully. They stressed that Hungarian readers have different requirements and expect fresh and interesting reporting on current news. ${ }^{68}$

Second, newspapers severely reduced Soviet topics. The intense decline was already registered by the agitprop organs in September 1953 when editors were warned about the worrying trends: the number of Soviet articles had been halved compared to January (except for Népszava) and some newspapers confined themselves to one or two such articles a month. ${ }^{69}$ Pál Tóth, the associate of the Agitation and Propaganda Department did not add that after the Beria-affair the Soviet Union almost disappeared from the press for a month. On the other hand - reflecting the internal tensions of the Hungarian Workers' Party, the different politics pursued by the Imre Nagy- and the Rákosi-wings - the press control organs produced two reports on Soviet propaganda in late 1954. The Agitation and Propaganda Department compiled a material stressing worrying trends: the number of articles on the Soviet Union had been reduced by more than $40 \%$ in one and a half years, but the decline between 1950 and 1954 considering the length of the articles was even more alarming: 89 columns compared to the four years earlier 262 columns, so only the third of the sometime content, however the circle of daily newspapers had broadened with Szabad Ifjúság. The material also held against the qualitative decay, the course of small news items and bouquets of information squeezing out larger comprehensive articles. On the other hand the Information Office established by Imre Nagy saw it differently. Acknowledging the qualitative decline, it talked about the failure of the whole former Soviet propaganda, the fiasco of achieving the ultimate goal - making the Hungarian people familiar with the Soviet Union and endearing it to the Hungarian public. As part of a new credible approach, the report proposed journalists' travels to the Soviet Union. In the later years - however

67 See: Irén SIMÁNDI, Magyarország a Szabad Európa Rádió hullámhosszán 1951-1956, Budapest 2005. 68 Records of the confidential press conference on 30 October 1953. MNL OL M-KS 276. f. 89/192. ő. e. 69 Records of the confidential press conference on 5 September 1953. MNL OL M-KS 276. f. 89/192. ő. e. 
after the forced resign of Imre Nagy - two large journalists' delegations and several report trips followed and Moscow correspondents were assigned.

This also contributed to a clear phenomenon of the de-Stalinization of the Soviet propaganda: professionalization. Journalists took back the power of defining the content - of course within the set limits. While in the years 1950 and 1952 journalist wrote less than $20 \%$ of the Soviet reports in Szabad Nép, this rate reached one-third in 1953 and in 1954 and constituted the two-thirds (or even more) later.

Chart 1. The number of Soviet reports in Szabad Nép by the distribution of the profession of the authors (\%).

\begin{tabular}{|l|l|l|l|l|l|l|l|l|l|}
\hline professionlyear & $\mathbf{1 9 5 0}$ & $\mathbf{1 9 5 1}$ & $\mathbf{1 9 5 2}$ & $\mathbf{1 9 5 3}$ & $\mathbf{1 9 5 4}$ & $\mathbf{1 9 5 5}$ & $\mathbf{1 9 5 6}$ & $\mathbf{1 9 5 7}$ & $\mathbf{1 9 5 8}$ \\
\hline journalist & 3.0 & 19.5 & 9.1 & 33.3 & 37.0 & 66.7 & 65.6 & 62.9 & 72.0 \\
\hline writer & 45.5 & 43.9 & 13.6 & 8.3 & 37.0 & 19.0 & 28.1 & 34.3 & 8.0 \\
\hline intellectual & 27.3 & 26.8 & 45.5 & 33.3 & 14.8 & 14.3 & 6.3 & 2.9 & 20.0 \\
\hline functionary & 0.0 & 2.4 & 22.7 & 16.7 & 7.4 & 0.0 & 0.0 & 0.0 & 0.0 \\
\hline worker/peasant & 18.2 & 7.3 & 0.0 & 8.3 & 3.7 & 0.0 & 0.0 & 0.0 & 0.0 \\
\hline other & 6.1 & 0.0 & 9.1 & 0.0 & 0.0 & 0.0 & 0.0 & 0.0 & 0.0 \\
\hline
\end{tabular}

Not only non-professional witnesses (intellectuals, workers, functionaries) disappeared but topics as well. Urban newspapers returned to urban questions according to the traditions of Budapest press. In the years of the great kolkhoz-propaganda of 1950 and 1951, 63.6\% and $65.9 \%$ of the articles of Szabad Nép processed rural topics. From 1952 it never passed $30 \%$ - even with articles that did not concentrate on but mentioned agricultural aspects. In some years agriculture had become a forgotten field - in 1954 only $8.3 \%$ and in 1958 4\% of the articles of Szabad Nép and Népszabadság touched upon rural Soviet Union. Of course this also reflected Hungarian politics, the fierceness and the easing of the collectivization campaigns in Hungary. However, the shift could be traced in grabbing the signs of modernization as well. Modern appearance was demonstrated by the cloakrooms and clothing of kolkhoz peasants before 1953 and by the supply of urban stores and Moscow fashion shows later. Women's emancipation first of all meant tractorist girls and kolkhoz leaders in 1950, but urban housewives equipped with modern household appliances in 1958. On the other hand it pushed back women from modern roles to traditional ones.

The changing attitudes of the de-Stalinized depiction of Soviet modernity could be summarized in three aspects. First, the late-Stalinist version was trying to find justification for ideological and political claims like disappearing differences between physical and intellectual work, city and village, men and women etc. As the Stalin-prize winner writer, Aczél Tamás registered in a Georgian kolkhoz about the peasants of Hucu: "they are wearing urban clothes, costumes or coats. This is the first but not the most decisive sample - to illustrate the slurring differences between village and town". ${ }^{70}$ And it sounded typical from the mouth of a Ukrainian kolkhoz leader when speaking about airplanes spraying fertiliz- 
ers as modern means of agricultural production: "Lo, our planes, the aeroplanes of the Soviet Union are the birds of peace and creation; while the aircrafts of the imperialists bring death to our Korean brothers". ${ }^{71}$ The new, de-Stalinized viewpoint announced that it discovers the things as they were: the Moscow underground with the drunken passenger, the Ukrainian villages with their muddy streets, the quickly built type-houses with floppy handles and Russian people with their outdated fashion. This meant that the still positive picture lost its coherence, since the observations were not any more inlaid into the intersections of the net of narratives.

Second, the chief achievements of the late Stalinist era stood as models to copy, the Soviet modernization was depicted as the only path to be followed to arrive to the same utopian land. Later on, copying was transcended and therefore the chief Soviet achievements and projects became something to consider, but often rather something to admire, to be proud of. Things which were suitable to prove the leading role of the Soviet Union like the synchrophasotron, the Sputnik, the TU-104 or the conquest of the virgin lands. From 1956, it has become possible - even current - to compare the Soviet and the Hungarian realities. And in some fields like severe temporary housing shortages, fashion, quality of food processing, Hungary could be presented in advantage.

And third the journalistic representation of the modern Soviet Union took a time travel from the present to the future. It was exactly the opposite direction where the de-Stalinization of politics was heading: from serving the world of future promises to serving the present demands of the society. This more general aspect of de-Stalinizaton was symbolized by the spinning-top motive of Ernő Mihalyfi. These articles concentrated on the changing emphasis from heavy industry to light industry, from automatized machines to the goods these assembly lines produced, from the scenes of production to the scenes where these products were bought and enjoyed. But the time travel of the other kind meant that the utopia of the present Soviet Union returned into a blurred future utopia. While the visitors of 1950 stepped into the future right at the borders when changing for the modern Soviet railway carriages, the reports from 1953 fit the Soviet utopia back into the future with the method learned from the Soviet press: showing up the perspectives, discovering the new, the emerging. Its symbol was the picture of the wooden houses next to the skyscrapers. It thrived to discover a world where the day before yesterday lived together with the day after tomorrow, and where the young conquered all the fields of life from the old. But in this time travel the coherent Soviet utopia fell into pieces.

\section{Epilogue}

Until 1958, Soviet modernity did not have to face an external challenge in its own territory - unless we take the rising level of Soviet tourism as a challenge. ${ }^{72}$ But the American exhibition at the Sokolniki Park in July and August 1959 brought the 'American utopia', the sheer but gorgeous consumerism to Moscow. As Péter Rényi, deputy editor in chief of

71 Mihály ZSURAKOVSZKI, Virágzó földek a sivatag helyén, Szabad Nép, 1951, Year 9, No. 191, 16 August.

72 On growing levels of Soviet tourism and its challenges on the image of Soviet modernity see: Anne E. GORSUCH, Time Travellers. Soviet Tourists to Eastern Europe, in: Turizm. The Russian and East European Tourist Under Capitalism and Socialism, Anne E. GORSUCH - Diane P. KOENKER (eds.), Ithaca 2006, 205-226. 
Népszabadság put it, the Americans complied a department store instead of an exhibition. "You could smoothly write the word 'Woolworth' on the multi-storeyed main exhibition hall". Rényi added: a poorish store: "you can see more diverse selection of goods at one single level of Detsky Mir in Moscow". However Rényi also acknowledged that American goods represented a higher quality, though in 1959 it was considered to be temporary, therefore irrelevant. "Just because here the inner design of the refrigerators is a bit more practical or the switches are nicer, was it really necessary to convey 25,000 tons of material from the other end of the world?" - he asked. And if something was undeniably modern like the IMB RAMAC computer that could answer 4,000 questions about America that was evaluated as used for the wrong purpose: mediating a false image of the Soviet Union. ${ }^{73}$ The section from the 1982 Népszabadság in the introduction shows that such arguments could not be credible two and a half decades later. After the vanishing of the utopia, the myth of successful modernization and overtaking the West also mouldered.

\section{Abstract}

The Stalinist Soviet Union integrated Hungary - and the nations of Central Europe - by 1949 forcing the Soviet-style political dictatorship and economic system to these societies and emphasizing the importance of the Soviet example in the modernization of all spheres from automation through cotton harvesting to public libraries. Stalinized publicity was saturated with information on the Soviet Union. After March 1953, it became clear that a different, more effective Soviet Union propaganda was necessary; however the first delegation of writers and journalists could only enter the Soviet Union in late 1955. December 1955 was the exact date of the launching of the first organized Hungarian tourist groups to Kiev, Leningrad and Moscow as well - after the 'years of delegations'. The revolution of 1956 brought another twist in this regard and efforts were made to shape a renewed friendly image of Khrushchev's empire.

Emphasis within modernization changed in this period - but the main goal of modernizing and overtaking the 'capitalist world' did not. The paper strives to reveal and analyse these changing attitudes and motives in depicting the Soviet Union as a modern empire. It thrives to explore the different threads in the de-Stalinization process - what changes stemmed from changing politics and policies, technical development and where we can grab the de-Stalinization of journalism and publicity.

\section{Keywords}

Utopia, modernization, Stalinization, de-Stalinization, Soviet Union, press, 1950s

\section{References}

Magyar Nemzeti Levéltár Országos Levéltára (MNL-OL)

The State Archives of the Hungarian National Archives

f. 276, Magyar Dolgozók Pártja Központi Szervei - Central Authorities of the Hungarian Working People's Party (1946-1958)

73 Péter RÉNYI, Amerikai kiállítás Moszkvában, Népszabadság, 1959, Year 17, No. 195, 20 August. 
Népszabadság, 1957, Year 2, No. 147, 206, 262.

Népszabadság, 1958, Year 16, No. 133, 183, 268, 308.

Népszabadság, 1959, Year 17, No. 195.

Népszabadság, 1982, Year 40, No. 113.

Magyar Nemzet, 1950, Year 6, No. 148.

Magyar Nemzet, 1953, Year 9, No. 192, 226.

Magyar Nemzet, 1957, Year 13, No. 16.

Magyar Nemzet, 1958, Year 14, No. 110, 137.

Szabad Nép, 1950, Year 8, No. 16, 28, 102, 196, 201, 205, 303.

Szabad Nép, 1951, Year 9, No. 12, 13, 15, 112, 191, 195, 198, 205.

Szabad Nép, 1952, Year 10, No. 28, 119, 127, 158, 220.

Szabad Nép, 1953, Year 11, No. 279.

Szabad Nép, 1954, Year 12, No. 167, 192, 208, 343.

Szabad Nép, 1955, Year 13, No. 5, 113, 162, 320, 356.

Szabad Nép, 1956, Year 14, No. 1, 20, 21, 121, 126, 136.

Statisztikai Évkönyv 1957, 1958.

BALOGH, Elemér: A vallás a Párt és az állam szempontjából, in: Társadalmi Szemle, 5, 1950, 7-8, 624-626.

BENCSIK, Péter - NAGY, György: A magyar úti okmányok története 1945-1989, Budapest 2003.

BITTNER, Stephen V.: The Many Lives of Khrushchev's Thaw: experience and memory in Moscow's Arbat, Ithaca 2008.

EDGAR, Adrienne Lynn: Tribal Nation: The Making of Soviet Turkmenistan, Princeton 2004.

GARAMVÖLGYI, Károly: A mezőgazdaság irányításának új vonásai a Szovjetunióban, in:

Társadalmi Szemle, 13, 1958, 7-8, 22.

GORSUCH, Anne E.: Time Travellers. Soviet Tourists to Eastern Europe, in: Turizm. The Russian and East European Tourist Under Capitalism and Socialism, GORSUCH, Anne E. - KOENKER, Diane P. (eds.), Ithaca 2006, 205-226.

INGLEHART, Ronald: Modernization and Postmodernization. Cultural, Economic and Political Change in 43 Societies, Princeton 1997.

PARKS, J. D.: Culture, Conflict and Coexistence. American-Soviet Cultural Relations, 19171958, Jefferson and London 1983.

ROTH-EY, Kristin: Finding a Home for Television in the USSR 1950-1970, in: Slavic Review, 66, 2007, 2, 278-282.

SIMÁNDI, Irén: Magyarország a Szabad Európa Rádió hullámhosszán 1951-1956, Budapest 2005.

SLEZKINE, Yuri: The USSR as a Communal Apartment, or How a Socialist State Promoted Ethnic Particularism, in: Slavic Review, 53, 1994, 2, 414-452.

SMITH, Mark B.: Khrushchev's promise to eliminate the urban housing shortage: rights, rationality and the communist future, in: Soviet State and Society under Nikita Khrushchev, ILIC, Melanie - SMITH, Jeremy (eds.), New York 2009, 29-33.

TAKÁCS, Róbert: Újságírói szerepfelfogások 1954 és 1956 között Magyarországon, in: Médiakutató, 7, 2006, Winter, 7-24.

TAUBMANN, William: Khrushchev: The Man and his Era, New York 2003. 
VARGA, György: S. Lilley: Az automatizálás és a társadalom, in: Közgazdasági Szemle, 5, 1958, 11, 1207-1209.

VARGA, Jenő: A jelenkori kapitalizmus és a szocializmus fejlődésének tendenciáiról, in: Társadalmi Szemle, 12, 1957, 10, 7-24.

WOLFE, Thomas C.: Governing Soviet Journalism. The Press and the Socialist Person After Stalin, Bloomington - Indianapolis 2005. 